\title{
MAD2L2 wt Allele
}

National Cancer Institute

\section{Source}

National Cancer Institute. MAD2L2 wt Allele. NCI Thesaurus. Code C116590.

Human MAD2L2 wild-type allele is located in the vicinity of 1 p36 and is approximately 17 $\mathrm{kb}$ in length. This allele, which encodes mitotic spindle assembly checkpoint protein MAD2B, is involved in the mitotic spindle assembly checkpoint and the modulation of translesional DNA synthesis. 